Vol. 11 (2002): 209-218.

\title{
A combined infrared/heat pump drying technology applied to a rotary dryer
}

Kirsti Pääkkönen

Department of Food Technology, PO Box 27, FIN-00014 University of Helsinki, Finland, e-mail: kirsti.paakkonen@helsinki.fi

\begin{abstract}
The short drying time and low product temperature makes it suitable for drying such heat-sensitive materials as herbs and vegetables. The purpose of this work was to develop a small-scale dryer for herbs and vegetables. A prototype rotary dryer combining infrared radiation with a so-called heat pump drying method was applied in drying experiments for several herbs and vegetables. The drying experiments were performed under actual crop production conditions. The drying curves for leaves of birch (Betula spp.), rosebay willowherb (Epilobium angustifolium) and dandelion (Taraxacum spp.) as well as slices of red beet (Beta vulgaris) and carrot (Daucus carota) are presented. During the drying operation, temperature and humidity of the drying air were recorded, as well as the energy consumed in drying. The quality parameters measured were water content, colour and rehydration ratio. In the present rotary dryer design, intermittent irradiation and mixing of the product enable to avoid overheating, which is particularly important for maintaining product quality. In this dryer design the drying drum slowly rotates and simultaneously mixes the product. The infrared heaters are attached to a panel, allowing the product to receive infrared radiation periodically.
\end{abstract}

Key words: Betula, Beta vulgaris, Daucus carota, Epilobium angustifolium, Taraxacum, infrared dryers, colour, drying curves, microbial flora, rehydration

\section{Introduction}

In recent years, attention has focused on the design and operation of a small-scale dryer for natural and biologically cultivated products. The underlying objective is to improve the quality of the dried products and to reduce the manpower required to conduct the drying operation. In the present study, drying curves play an important role in optimizing the utilization of a given dryer because they can be used to define the optimal conditions for drying time and energy consumption (Tsamparlis 1992). Low-temperature drying with infrared radiation has been shown to be a potentially useful method for preserving heat-sensitive natural products since it is gentle and shortens the processing time significantly (Pääkkönen et al. 1999). Studies focusing on drying kinetics of products show that the drying 


\section{Pääkkönen, K. A combined infrared/heat pump drying technology}

temperature and water content of the drying air are the main factors controlling the drying rate. The initial stage of the convection drying of herbs and vegetables may be predicted by heat and mass transfer equations (Techasena et al. 1992, Belghit et al. 2000). If the shrinkage effect dependent on water diffusion and on temperature are taken into account, it is a difficult task to define the physical constants needed to solve the equations (Pabis 1999, Yaldýz and Ertekýn 2001). In convection drying the temperature of the drying air is the main factor influencing the drying rate, if no secondary heat sources are considered. In near-infrared drying, radiation energy is transferred from the heating element to the product surface without heating the surrounding air. Drying temperature is dependent on the distance of the material from the emitter (Chu et al. 1992, Parrouffe et al. 1992, Ratti and Crapiste 1992, Zbicinski et al. 1992, Abe and Afzal 1997). Umesh Hebbar and Rastogi (2001) have studied mass transfer and Ranjan et al. (2002) heat and mass transfer in infrared drying systems. In the current design the drying drum rotates slowly and simultaneously mixes the product. The infrared heaters are attached to a panel, allowing the product to receive infrared radiation periodically. Low product temperature makes the device suitable for drying heat-sensitive plant material. In drying at temperatures below $50^{\circ} \mathrm{C}$, the drying capacity of the air at the dryer entrance can be increased by forcing it first through the heat pump dryer, where its moisture content is reduced due to condensation of water vapour. Rossi et al. (1992) demonstrated that drying food with a heat pump resulted in energy savings and better product quality due to shorter processing times.

The purpose of this work was to develop a small-scale dryer for herbs and vegetables combining infrared radiation with heat pump drying. The specific objectives for the drying experiments were to determine the temperatures inside the dryer and the dynamic moisture changes occurring during drying as well as the effect of drum rotation on the thickness and width of product slices.

\section{Material and methods}

Birch (Betula spp.), dandelion (Taraxacum spp.) and rosebay willowherb (Epilobium angustifolium) were grown at Savonlinna, Finland. Carrot (Daucus carota) and red beet (Beta vulgaris) were grown at Mikkeli, Finland. Birch, dandelion and rosebay willowherb leaves were harvested before blooming and dried immediately after harvesting. Slices of $2.5-5 \mathrm{~cm}$ of carrot and red beet were dried within $24 \mathrm{~h}$. The dryer was loaded with $27-43 \mathrm{~kg}$ of fresh product. When drying was carried out using a drum even mixing and temperature distribution within the cuttings, as well as drying curves for herbs and vegetables could be obtained.

\section{Rotary dryer}

A prototype rotary dryer (Fin patent no. 3729) using infrared radiation combined with a heat pump was built by Kesvent Ltd., Kesälahti, Finland. The walls of the dryer are stainless-steel sheets with a layer of rock wool insulation. The drying chamber measures $1260 \times 1260 \times$ $1550 \mathrm{~mm}$ equipped with a drum of overall length $870 \mathrm{~mm}$ and diameter $430 \mathrm{~mm}$. The drum is divided radially into eight compartments covered with galvanized wire of ISS 200 mesh size (corresponding to a $2.5-\mathrm{mm}$ width of the openings). The near-infrared panel heater was composed of two lamps, each $300 \mathrm{~mm}$ in length. The nominal power of each lamp was $3 \mathrm{~kW}$. The infrared heaters are attached to a panel at a distance of 300 $\mathrm{mm}$ from the drying drum. The rotation of the drum timed the infrared radiation period and duration: the speed of rotation was $0.3 \mathrm{rpm}$, and the direction of rotation changed at intervals of $180 \mathrm{~s}$ so that the product in each compartment is heated during about $22.5 \mathrm{~s}$ every $3 \mathrm{~min}$. In this design the drying drum slowly rotates and simultaneously mixes the product. The periods of irradiation alternated with periods of exposure to ambient air temperature. During the cooling periods the temperature gradient within the ma- 
Vol. 11 (2002): 209-218.

terial reversed, and the displacement of moisture towards the evaporation zone intensified. A heat pump with an open-type, reciprocal compressor linked to a 5-HP electric motor served as a dehumidifier-heater for the ambient air used in drying of products. The refrigerant (R22), used with an air condenser employing dry expansion evaporation $\left(20 \mathrm{~m}^{2}\right)$, was suitable for condensing and draining moisture from the inlet air. The air flowed into the drying chamber at a rate of $13 \mathrm{~ms}^{-1}$, versus a calculated average rate of $1.2 \mathrm{~ms}^{-1}$ in the drying drum. The outlet air temperature was measured and controlled using a manual variable transformer. The construction of the dryer is shown in Fig.1.

\section{Drying experiments}

The drying curve was established by taking samples at $1 \mathrm{~h}$ intervals during the drying process. The moisture contents of the samples were determined by heating in an oven at $105^{\circ} \mathrm{C}$ for at least $12 \mathrm{~h}$ and by weighing the samples to constant weight with an electric balance $( \pm 0.001 \mathrm{~g})$ (Precisa 180A).

\section{Rehydration}

The product $(2.5 \mathrm{~g})$ was immersed in $(50 \mathrm{ml})$ distilled water at $23^{\circ} \mathrm{C}$ for $15 \mathrm{~min}$.; excess water was drained off using filter paper. The ratio of water absorbed by unit weight of the dried samples was determined. The rehydration measurements were repeated 3 times and the mean ratios reported. The rehydration capacity of the dried slices was also determined by measuring their width and thickness (24 samples) before and after rehydration with an electronic digital calliper (Wurth AG, Germany).

\section{Colour measurements}

Sample colour was measured using a Minolta Crome CR-200 colour meter (Minolta Camera

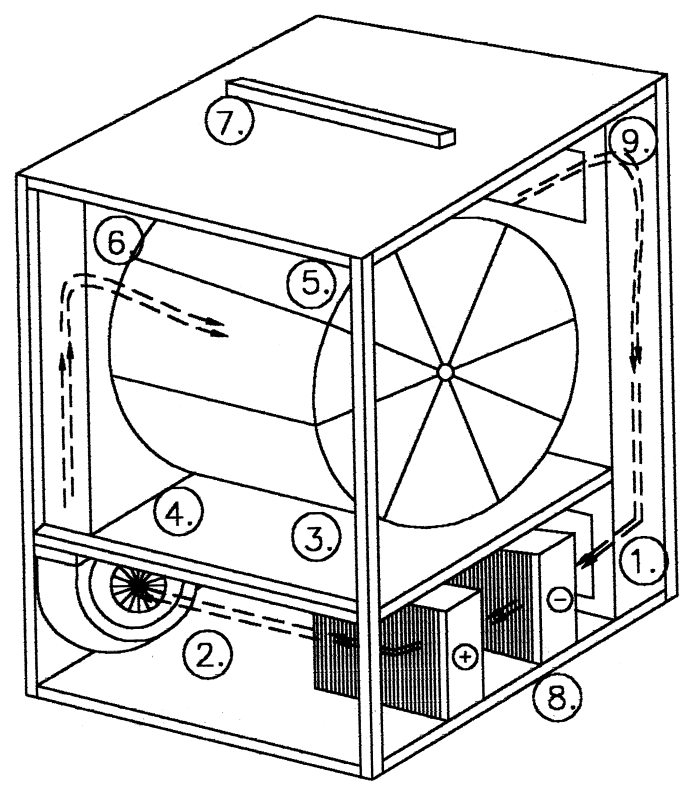

Fig. 1. Schematic of dryer; control thermocouples (1-8) and measuring thermocouple (9).

Co. Ltd, Japan). Three measurements were taken at random locations of sliced fresh and dried samples, and the mean was reported. The colour readings were expressed by the ICI chromaticity coordinates system, in which subscript 0 refers to the colour reading of the fresh sample and $\mathrm{L}^{*}, \mathrm{a}^{*}$ and $\mathrm{b}^{*}$ indicate brightness, redness and yellowness, respectively. The colour difference from the fresh samples $\Delta \mathrm{E}^{*}$ ab was used to describe the colour change during drying. The larger the value for $\Delta \mathrm{E}^{*} \mathrm{ab}$, the greater the colour change from the reference colour of the fresh sample. Samples were analysed in triplicate for colour content.

\section{Microbiological analysis}

The microbiological quality of the fresh and dried material was determined for total bacterial count according to ISO 4833/91, coliforms were determined according to ISO 4832/91 and moulds and yeasts according to NMKL (1995). 


\section{Monitoring}

Dryer operation was monitored continuously for the period of the experiment with a Honeywell DPR 3000 and PC-based measuring system. Eight thermoelements measured temperature changes inside the chamber throughout the drying process. The temperatures and humidities of the intake and exhaust air were measured with sensors. Exhaust airflow was recorded with an Alnor Thermo-Anemometer GGaA-65. Electrical power was measured with an Enermet K320NXEp meter.

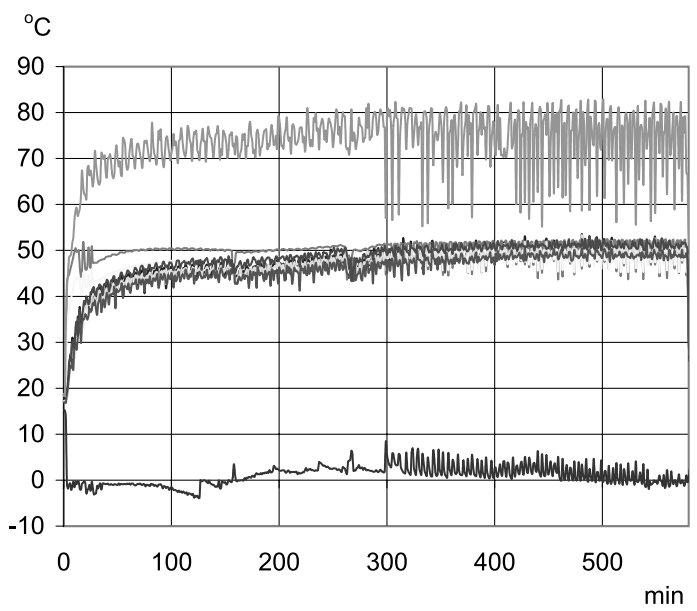

Fig. 2. Temperature gradients inside the dryer during drying at $50^{\circ} \mathrm{C}$; Diagrams (upper) near infrared lamps, (middle) in drying chamber, (lower) after condensing.

\section{Results and discussion}

The drying experiments were performed as a function of the operating parameters, namely, temperature and humidity, drying time and energy consumption. The only continuously controlled parameter was temperature of the circuit airflow inside the drying chamber. Thermal insulation from the ambient air is important in the drying process. The temperature gradients inside the dryer during the drying operation are shown in Fig. 2. Temperature changes monitored inside the drying chamber during drying indicated the temperature variation with time as well as location. The average temperatures obtained at the different locations in the dryer for three levels of dry air temperature are shown at Table 1 . The standard deviation characterizes threir fluctuation with time. The first hundred minutes to acquire the steadiness of the temperature are not included when calculating the temperatures (See in Fig. 2.). The drying temperature was dependent on the infrared radiation and the temperature of the drying air. When plant materials are dried, the maximum temperature reached by the product is a very critical variable. The temperature of the wet air remained relatively low; however, towards the end of the drying process the air temperature generally rose to the average level existing inside the drying chamber. With the temperature control system (See in Fig. 1.) adjusted for a given temperature, the cooling ef-

Table 1. Temperature deviations inside drying chamber during drying at different temperatures.

\begin{tabular}{lcccccc}
\hline & \multicolumn{7}{c}{ Temperatures inside drying chamber $\left({ }^{\circ} \mathrm{C}\right)$} \\
\cline { 2 - 6 } & Mean & STD & Mean & STD & Mean & STD \\
\hline Wet air & 27.3 & 2.4 & 35.5 & 1.6 & 45.3 & 1.2 \\
Dry air & 32.0 & 3.9 & 36.4 & 2.2 & 48.2 & 4.9 \\
Botton right & 30.2 & 3.6 & 34.0 & 3.4 & 46.5 & 4.8 \\
Botton left & 30.4 & 3.7 & 38.4 & 1.8 & 48.1 & 2.8 \\
Top right & 32.0 & 3.5 & 37.4 & 2.3 & 50.0 & 3.4 \\
Top left & 30.0 & 3.8 & 38.8 & 1.6 & 46.8 & 5.0 \\
\hline
\end{tabular}

STD $=$ Standard deviation 
Vol. 11 (2002): 209-218.

Table 2. Sample weight, drying temperature and time, moisture of fresh and dried plants and energy consumption in infrared drying experiments.

\begin{tabular}{|c|c|c|c|c|c|c|}
\hline Plant & $\begin{array}{c}\text { Drum initial } \\
\text { load, } \\
\text { kg }\end{array}$ & $\begin{array}{c}\text { Drying } \\
\text { temperature, } \\
{ }^{\circ} \mathrm{C}\end{array}$ & $\begin{array}{c}\text { Drying } \\
\text { time, } \\
\mathrm{h}\end{array}$ & $\begin{array}{l}\text { Moisture of } \\
\text { fresh plant, } \\
\% \text { w/w }\end{array}$ & $\begin{array}{l}\text { Moisture of } \\
\text { dried plant, } \\
\% \text { w/w }\end{array}$ & $\begin{array}{l}\text { Energy } \\
\text { consumption, } \\
\mathrm{kWh} \mathrm{kg}^{-1} \mathrm{H}_{2} \mathrm{O}\end{array}$ \\
\hline \multirow[t]{2}{*}{ Birch leaf } & 40 & 40 & 12 & 69 & 12 & 3.6 \\
\hline & 43 & 50 & 9 & 69 & 10 & 3.1 \\
\hline Dandelion & 27 & 40 & 12 & 80 & 12 & 4.5 \\
\hline Rosebay willowherb & 38 & 40 & 10 & 81 & 12 & 2.9 \\
\hline Red beet & 40 & 40 & 12 & 87 & 12 & 1.5 \\
\hline Carrot & 30 & 40 & 12 & 91 & 18 & 1.6 \\
\hline
\end{tabular}

fect of convection allows higher radiative conditions and shorter drying time. In experiments the temperature inside the dryer was maintained at $40-50^{\circ} \mathrm{C}$. The drying experiments were carried out at a constant air flowrate. The relative humidity of the drying air was $16.7-14.1 \% \mathrm{rH}$ in the first drying period and $11.4-10.2 \% \mathrm{rH}$ at the end of drying. The relative humidity of the inlet air and the evaporation temperature were considered to be the major parameters limiting the applicability of this system. Table 2 shows the results of the drying experiments: drying temperature and time, moisture content of the product and energy consumption.

In drying at $40^{\circ} \mathrm{C}$ about $12 \mathrm{~h}$ are required to reduce the moisture content to a level of $12 \%$. To compare drying methods, the energy requirements per unit weight of water removed during drying is a relevant criteria. It was the lowest (1.5 $\mathrm{kWh} \mathrm{kg}^{-1} \mathrm{H}_{2} \mathrm{O}$ ) in drying of vegetable slices having an initial water contents of about $90 \%$. For the herbs (2.9-4.5 $\mathrm{kWh} \mathrm{kg}^{-1} \mathrm{H}_{2} \mathrm{O}$ ) it also depended on the loading of the drying drum. Energy consumption was maximum with the minimum loading. In the earlier static bed infrared drying experiments with air convection (Pääkkönen et al. 1999), the mean energy consumption (4.6 $\mathrm{kWh} \mathrm{kg}^{-1} \mathrm{H}_{2} \mathrm{O}$ ), was higher than in the present drum drying experiments (3.3 $\mathrm{kWh} \mathrm{kg}^{-1} \mathrm{H}_{2} \mathrm{O}$ ) confirming that drum drying with a heat pump results in energy savings. The drying time can be shortened and energy consumption reduced by drying at higher tem-

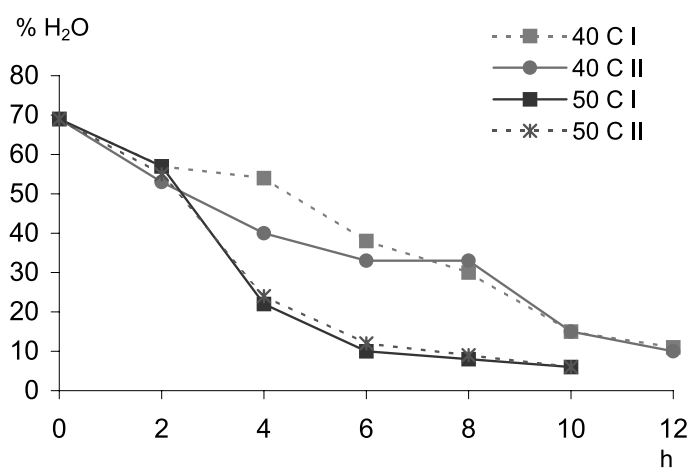

Fig. 3. Drying curve of birch leaves at 40 and $50^{\circ} \mathrm{C}$; I and II are two different experiments.

peratures (Fig. 3, Table 2). However, the low temperature contributes to retain useful properties. Although the drying study of Keinänen and Julkunen-Tiitto (1996) at $40^{\circ} \mathrm{C}$ and $80^{\circ} \mathrm{C}$ showed that flavonoids and glycosides of birch leaf are relatively thermostable, it must also be considered that thermal denaturation of enzymes usually begins at temperatures of about $40-50^{\circ} \mathrm{C}$. The drying temperature will be selected according to the expected properties of the end products.

Water evaporation rate in the capillary condensation phase was very high (Figs. 4 and 5). Water evaporation is dependent on the structure and surface properties of the material and water sorption, eg. the bound water phase, is dependent on the molecular structure and chemical composition of the material (Pääkkönen 1987). It is 
Pääkkönen, K. A combined infrared/heat pump drying technology

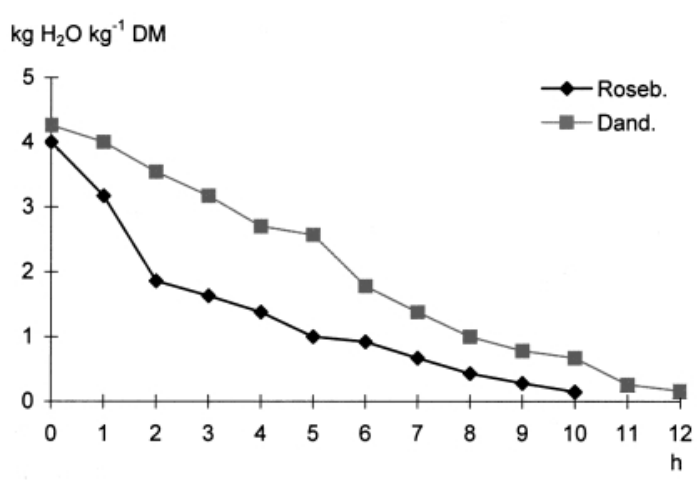

Fig. 4. Drying kinetics of rosebay willowherb and dandelion at $40^{\circ} \mathrm{C}$.

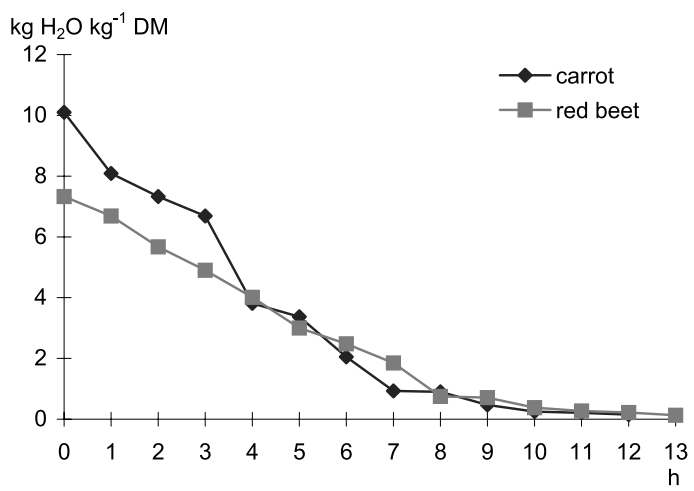

Fig. 5. Drying kinetics of carrot and red beet at $40^{\circ} \mathrm{C}$. shown in irregular shape of the drying curves. Fig. 4 shows the drying rate curves of herb leaves at $40^{\circ} \mathrm{C}$. The average drying rate for rosebay willowherb was $0.474 \mathrm{~kg} \mathrm{H}_{2} \mathrm{O} \mathrm{kg}^{-1} \mathrm{DM}$ (dry matter) during the first 7 hours and is similar to that for dandelion $\left(0.411 \mathrm{~kg} \mathrm{H}_{2} \mathrm{O} \mathrm{kg}^{-1} \mathrm{DM}\right)$. Figure 5 shows the drying rate curves for the slices of red beet and carrot. The average drying rate during the first 7 hours for the carrot slices was 1.206 and for beet root $0.783 \mathrm{~kg} \mathrm{H}_{2} \mathrm{O} \mathrm{kg}^{-1} \mathrm{DM}$, which were remarkably higher than for the herb leaves (Fig. 4). This results from the differing bound water content in the cell structure of fresh plants and the water evaporation in the unshielded surface of the cuttings.

The fresh plant is an essential factor in determining the quality of the dried herbs. Although closer identification of the aerobic plate count (APC) group in herbs was not attempted, aerobic sporeformers and moulds were detected in almost all herb samples (Malmsten et al. 1991). The drying experiment of Pääkkönen et al. (1999) indicated that infrared radiation in lowtemperature drying did not affect the microbial quality of herbs, but that drying temperature clearly affected microbial quality. Microbial analysis of the herbs during the drying operation (Table 3) shows that at the first half of dry-

Table 3. Number of microflora per gram in fresh herbs and during infrared drying. Two samples were taken from each plant.

\begin{tabular}{|c|c|c|c|c|c|}
\hline Plant & Drying time, $\mathrm{h}$ & APC & Coliform & Moulds & Yeasts \\
\hline \multicolumn{6}{|l|}{ Birch leaf } \\
\hline fresh & 0 & $<1000$ & $<10$ & 400 & 29000 \\
\hline \multirow[t]{2}{*}{ dried $\left(40^{\circ} \mathrm{C}\right)$} & 10 & 4000 & 0.1 & 1100 & 900 \\
\hline & 11 & 2000 & 0.1 & 500 & 1400 \\
\hline \multirow[t]{3}{*}{ dried $\left(50^{\circ} \mathrm{C}\right)$} & 2 & $<1000$ & $<10$ & 200 & 1400 \\
\hline & 4 & 4000 & $<10$ & $<100$ & 53000 \\
\hline & 9 & $<1000$ & $<10$ & 200 & $<100$ \\
\hline \multicolumn{6}{|c|}{ Rosebay willowherb } \\
\hline fresh & 0 & 104000 & $<0$ & $<100$ & 18000 \\
\hline \multirow[t]{3}{*}{ dried $\left(40^{\circ} \mathrm{C}\right)$} & 2 & 480000 & $<0$ & $<100$ & 28800 \\
\hline & 5 & 168000 & $<0$ & $<100$ & 35600 \\
\hline & 10 & 310000 & $<0$ & $<100$ & 23000 \\
\hline
\end{tabular}

$\mathrm{APC}=$ Aerobic plate count 
Vol. 11 (2002): 209-218.

ing, the temperature and humidity conditions in the drying chamber might be favourable for microbes. The APC and yeast counts were slightly lower for fresh herbs than for samples dried at $40^{\circ} \mathrm{C}$; only yeasts were destroyed in drying at $50^{\circ} \mathrm{C}$.

In drying experiments colour and rehydration capacity of the different dried samples were compared as individual quality attributes for the fresh/dried products. Colour plays an important role in consumer acceptance of a product because the primary impression of food is a visual one. Beet pigments are natural food colourants; losses of the main red beet pigments (betanine and vulgaxanthin) during dehydration occur simultaneously with respect to both temperature and moisture content (Saguy et al. 1980, Krokida et al. 2001). The results of colour analysis of dried birch and rosebay willowherb leaves and dried beet root and carrot slices are presented in Table 4 . The colour difference values $\Delta \mathrm{E}^{*}$ for the birch leaves dried at different temperatures (40 and $50^{\circ} \mathrm{C}$ ) were similar, suggesting that the temperature difference did not affect their colour. The colour of the rehydrated sample is also a critical quality factor for the dried product. In the case of red beet and carrot slices the $\Delta \mathrm{E}^{*}$ value for the rehydrated sample was lower than that for dried. The colour difference value between fresh and rehydrated carrot slices was very much lower (7.90) than that between fresh and dried slices (16.37) suggesting that the colour of the processed food is mainly dependent on the water content of the products. However, in processing, permanent degradation of colour is caused by oxidation of pigments and interstitial melting.

Ideally, rehydration of a food product uptakes the amount of moisture lost during dehydration. The capacity of dried foods to absorb water varies with different drying treatments (Schalde et al. 1983). For comparison a sample of red beet slices was dried in a static bed infrared dryer (Pääkkönen et al. 1999) for use in rehydration analysis. The rehydration capacity for the red beet slices dried in the drum dryer and in static dryer and for carrot slices in the drum dryer was $96 \%, 93 \%$ and $99 \%$, respectively. In static bed drying the shape of the slices remained unchanged, while the drum-dried slices were crooked, which was caused by the rotation effect of the drying drum. The results of the rehydration experiment of the differently dried red beet slices, which was performed to examine the quality of the dried product, are shown in Fig. 6 together with the results of a t-test comparison of the

Table 4. Colour analysis of fresh, dried and rehydrated samples.

\begin{tabular}{|c|c|c|c|c|}
\hline & $\begin{array}{l}\text { Lightness } \\
\text { L }^{*}\end{array}$ & $\begin{array}{l}\text { Redness } \\
\mathrm{a}^{*}\end{array}$ & $\begin{array}{c}\text { Yellowness } \\
\text { b* }\end{array}$ & $\begin{array}{c}\text { Colour difference } \\
\Delta \mathrm{E}^{*}\end{array}$ \\
\hline \multicolumn{5}{|l|}{ Birch } \\
\hline fresh & 33.84 & -10.20 & 13.51 & \\
\hline dried $\left(40^{\circ} \mathrm{C}\right)$ & 40.50 & -8.83 & 12.43 & 6.93 \\
\hline dried $\left(50^{\circ} \mathrm{C}\right)$ & 39.48 & -8.20 & 17.12 & 6.96 \\
\hline \multicolumn{5}{|c|}{ Rosebay willowherb } \\
\hline fresh & 33.88 & -13.03 & 14.18 & \\
\hline dried $\left(40^{\circ} \mathrm{C}\right)$ & 33.22 & -7.94 & 13.12 & 5.37 \\
\hline \multicolumn{5}{|l|}{ Beet root } \\
\hline fresh & 33.63 & 11.17 & -0.31 & \\
\hline dried $\left(40^{\circ} \mathrm{C}\right)$ & 38.31 & 1.77 & -1.16 & 8.83 \\
\hline rehydrated & 34.03 & 3.07 & -0.44 & 6.32 \\
\hline \multicolumn{5}{|l|}{ Carrot } \\
\hline fresh & 60.78 & 32.50 & 34.80 & \\
\hline dried & 54.59 & 27.70 & 20.42 & 16.37 \\
\hline rehydrated & 54.29 & 32.33 & 30.29 & 7.90 \\
\hline
\end{tabular}


Pääkkönen, K. A combined infrared/heat pump drying technology

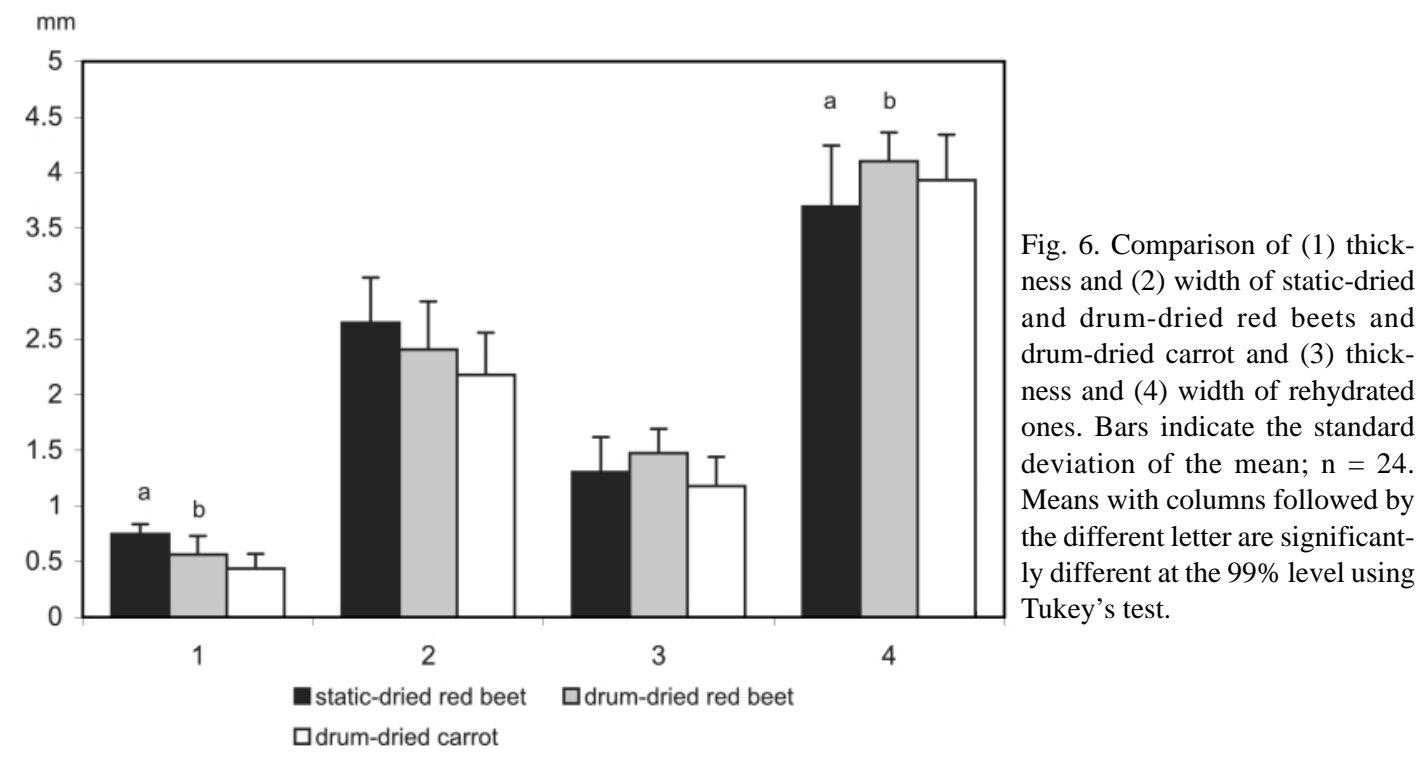

mean scores of the drum-dried carrot and samples of the dried beet root. Comparison of the data of drum- and static-dried samples in the case of red beet revealed significant differences $(\mathrm{P}<$ 0.1 ) between thickness of the dried samples and between width of the rehydrated samples. In drying the maximum temperature relating to the plants is a very critical variable. In static drying infrared radial heating caused melting by rapid reduction of surface moisture that could be seen as a perseptible reduction in rehydration capacity of the static-dried compared with the drum-dried sample. In the present drum dryer design, intermittent irradiation and mixing of the product enable to avoid overheating, which is particularly important for maintaining product quality.

\section{Conclusions}

The drum drying technique developed here effectively combined infrared drying and heat pump drying operations in one device. In this dryer design the drum slowly rotates and simultaneously mixes the product, allowing the product to receive infrared radiation periodically, leading to a very short drying time. Its capability for drying small particulate foods was investigated. Consequently the short drying time and low drying temperature are the factors which make this procedure suitable for drying such heat-sensitive materials as herbs and vegetables.

Sponsoreship. National Techology Agency 
Vol. 11 (2002): 209-218.

\section{References}

Abe, T. \& Afzal, T.M. 1997. Thin-layer infrared radiation drying of rough rice. Journal of Agricultural Engineering Research 67: 289-297.

Belghit, A., Kouhila, M. \& Boutaleb, B.C. 2000. Experimental study of drying kinetics by forced convection of aromatic plants. Energy Conversion \& Management 41: 1301-1321.

Chu, Z., Liu, J., Meng, X., Wang, Q. \& Jiao, S. 1992. Experimental research on optimizing of biological material. In: Mujumdar, A.S. (ed.). Drying '92. Elsevier Science Publisher B.V. p. 1729-1738.

ISO 4832/91. General guidance of the enumeration of coliforms. Colony count technique. The International organization for standardization 1991.

ISO 4833/91. General quidance for the enumeration of micro-organisms. Colony count technique at $30 \mathrm{de-}$ grees $C$. The International organization for standardization 1991.

Keinänen, M. \& Julkunen-Tiitto, R. 1996. Effect of sample preparation method on birch (Betula pendula Roth) leaf phenolics. Journal of Agricultural and Food Chemistry 44: 2724-2727.

Krokida, M.K., Maroulis, Z.B. \& Savaracos, G.D. 2001. The effect of the method of drying on the colour of dehydrated products. International Journal of Food Science and Technology 36: 53-59.

Malmsten, T., Pääkkönen, K. \& Hyvönen, L. 1991. Packaging and storage effects on microbiological quality of dried herbs. Journal of Food Science 56: 873-875.

NMKL 98/95. Mögel och jäst. Bestämning. Nordic Committee on Food Analysis 98: 3ed edition. 1995.

Pääkkönen, K. 1987. The water sorption of chitin isolated from the Northern Milk Cap mushroom (Lactarius trivialis). Lebensmittel-Wissenschaft und-Technologie 20: 259-262.

Pääkkönen, K., Havento, J., Galambosi, B. \& Pyykkönen, M. 1999. Infrared drying of herbs. Agricultural and Food Science in Finland 8:19-27.

Pabis, S. 1999. The initial phase of convection drying of vegetables and mushrooms and the effect of shrink- age. Journal of Agricultural Engineering Research 72: 187-195.

Parrouffe, J.-M., Dostie, M., Mujumdar, A.S. \& Poulin, A. 1992. Convective transport in infrared drying. In: Mujumdar, A.S. (ed.). Drying '92. Elsevier Science Publisher B.V. p. 695-703.

Ranjan, R., Irudayaraj, J. \& Jun, S. 2002. Simulation of infrared drying process. Drying Technology 20: 363379.

Ratti, C. \& Crapiste, G.H. 1992. A generalized drying curve for shrinking food materials. In: Mujumdar, A.S. (ed.). Drying '92. Elsevier Science Publisher B.V. p. 864-873.

Rossi, S.J., Neves, L.C. \& Kierckbuch, T.G. 1992. Thermodynamic and energetic evaluation of heat pump applied to the drying of vegetables. In: Mujumdar, A.S. (ed.). Drying '92. Elsevier Science Publisher B.V. p. $1475-1484$.

Saguy, I., Kopelman, I.J. \& Mizrahi, S. 1980. Computeraided prediction of beet pigment (Betanine and Vulgaxanthin-1) retention during air-drying. Journal of Food Science 45: 230-235.

Schadle, E.R., Burns, E.E. \& Talley, L.J. 1983. Forced air drying of partially freeze-dried compressed carrot bars. Journal of Food Science 48: 193-196.

Techasena, A., Lebert, A. \& Bimbenet, J.J. 1992. Simulation of deep bed drying of carrots. Journal of Food Engineering 16: 267-281.

Tsamparlis, M. 1992. The role of laboratory drying curves in practice. In: Mujumdar, A.S. (ed.). Drying '92. Elsevier Science Publisher B.V. p. 1808-1813.

Umesh Hebbar, H. \& Rastogi, N.K. 2001. Mass transfer during infrared drying of cashew kernel. Journal of Food Engineering 47: 1-5.

Zbicinski, I., Jakobsen, A. \& Driscoll, J.L. 1992. Application of infra-red radiation for drying of particulate materials. In: Mujumdar, A.S. (ed.). Drying '92. Elsevier Science Publisher B.V. p. 704-711.

Yaldýz, O. \& Ertekýn, C. 2001. Thin layer solar drying of some vegetables. Drying Technology 19: 583-597. 
Pääkkönen, K. A combined infrared/heat pump drying technology

\title{
SELOSTUS
}

\section{Yrttien ja vihannesten infrapunakuivaus rumpukuivurissa}

\author{
Kirsti Pääkkönen \\ Helsingin yliopisto
}

Infrapunakuivaus on yrttien ja vihannesten kuivaukseen soveltuva menetelmä, jonka käyttö vaatii laitteiston, jossa kuivattava materiaali liikkuu niin, että kuivuminen tapahtuu tasaisesti. Kokeissa kuivattiin koivun, horsman ja voikukan lehtiä sekä porkkanaja punajuurilastuja. Tutkimukseen rakennettiin ruostumattomasta materiaalista putkirunkoinen ja ulkopinnoiltaan lämpöeristetty kuivauslaitteisto.

Kuivausrumpu on jaettu kahdeksaan segmenttiin, joissa on luukut täyttöä ja tyhjennystä varten. Rummun ulkopinta on teräsverkkoa. Laitteistossa on ilmankiertojärjestelmä, jossa kuivaa ja valitun lämpöistä ilmaa kierrätetään kuivattavan materiaalin läpi. Ilma kuivataan ja lämmitetään lämpöpumpun avulla ja puhalletaan uudelleen kuivattavan materiaalin läpi. Kuivumista nopeutetaan infrapunalamppujen avulla.
Kuivausrummun pyörivä liike jaksottaa infrapunalamppujen säteilyn materiaaliin. Kerrallaan kuivattiin $30-40 \mathrm{~kg}$. Kuivauslämpötilat olivat $40-50^{\circ} \mathrm{C}$. Kuivurin sisälämpötila pysyi kuivauslämpötilan asetuksen mukaisena koko kuivauksen ajan. Kuivausrummun jälkeinen kuivausilman vesipitoisuus oli noin $12 \%$ kuivauksen lopussa. Kuivauslämpötilan nostaminen nopeutti kuivumista. Yrttien lehdet kuivuivat $12 \%$ :n vesipitoisuuteen 12 tunnissa. Hiivojen pitoisuus pieneni kuivattaessa $50^{\circ} \mathrm{C}$ :ssa. Tutkimuksen tulokset osoittivat, että rumpukuivauslaitteisto, jossa kuivaus tapahtuu yhdistetyllä infrapuna- ja lauhdekuivaustekniikalla sopii hyvin yrttien lehtien ja silputtujen juuresten kuivaukseen. Materiaali kuivui nopeasti ja lopputuote oli hyvälaatuista. 